\section{Anesthesia in Mowat-Wilson syndrome: information on 11 Italian patients}

\author{
Marianna Spunton, ${ }^{1}$ Livia Garavelli, 2 \\ Paola Cerutti Mainardi, 3 Uta Emmig, 4 \\ Enrico Finale, ${ }^{1}$ Andrea Guala1 \\ 1Department of Pediatrics, Castelli \\ Hospital, Verbania; ${ }^{2}$ Clinical Genetics \\ Unit, Obstetric and Pediatric \\ Department, S. Maria Nuova Hospital, \\ Reggio Emilia; ${ }^{3}$ Department of \\ Pediatrics, S. Andrea Hospital, Vercelli; \\ ${ }^{4}$ Department of Anesthesia, S. Biagio \\ Hospital, Domodossola, Italy
}

\begin{abstract}
Mowat-Wilson syndrome is a genetic disease caused by heterozygous mutations or deletions of the ZEB2 gene and characterized by typical clinical features. The congenital malformations typical of this syndrome call for early diagnostic and surgical procedures requiring general anesthesia, but few information about the anesthesiology management of such patients is available. We enrolled 11 families of patients with Mowat-Wilson syndrome who had undergone surgical or diagnostic procedures requiring general anesthesia, and sent them a retrospective questionnaire including 16 open questions about the procedures. They were further contacted by phone for a semistructured interview. A total of 37 procedures requiring general anesthesia was reported in 11 patients. Only two patients reported anesthesia-related complications during the procedure. No true additional anesthesiarelated risk was present for the patients with MW syndrome, besides difficult intubation, weaning and lower respiratory tract infection. Perception of risk, however, is derived by non-medical observation on the part of the parents.
\end{abstract}

\section{Introduction}

Mowat-Wilson syndrome (MWS; OMIM\#235730) is a genetic disease caused by heterozygous mutations or deletions of the ZEB2 gene,1,2 and characterized by typical face, epilepsy, moderate-to-severe mental retardation, and variable congenital malformations, including Hirschsprung disease (HSCR), agenesis of the corpus callosum (ACC), congenital heart disease (CHD), genital anomalies (particularly hypospadias in males), and eye defects.
Since the first delineation by Mowat et al. (1998), more then 200 patients with ZEB2 mutations, deletions or cytogenetic abnormalities have been reported primarily from Northern Europe, Australia, Italy and the United States, and over 100 mutations have been described. ${ }^{3-17}$

Congenital malformations typical of this syndrome call for early diagnostic investigations and surgical resolutions; general anesthesia is required for diagnostic and surgical procedures, both in election and in emergency, but few information about anesthesiologic management is available. ${ }^{9}$

The aim of our study was to collect retrospective data on general anesthesia interviewing a large numbered group of Italian patients with MWS, assess the anesthesiologic outcomes and identify the conditions that required general anesthesia; aware of the fact that few clinical data would be derived from this interview

\section{Materials and Methods}

A retrospective cohort study design was performed with questionnaire was sent to the parents using the mailing list of the Italian association of the Mowat-Wilson Syndrome. Thirty six questionnaires were sent out in total and each questionnaire included 16 open questions about age, type of surgery/diagnostic test requiring general anesthesia and outcome of the procedure. Some questions relating to the perception of the families about the knowledge of the disease by the anesthesiologist were also included. All of the families who initially replied to the questionnaire by mail were then contacted by phone for an additional semistructured interview.

Furthermore a further call was necessary to obtain clinical data such as the hospital stay from the clinical documentation in the possession of the families.

\section{Results}

We have collected questionnaires from 11 patients with MWS on thirty six.

A total of 37 anesthesiologic procedures was reported in 11 patients; in all cases, anesthesia was required in relation to various type of surgery and diagnostic procedures (Table 1).

The age of surgery and diagnostic procedures is reported in Figure 1.

The more common operations were the following: gastrointestinal surgeries $(27 \%)$; diagnostic investigation, mainly MRI $(24,3 \%)$; cardiac surgeries $(16,2 \%)$; orchiopexy/orchiectomy of a cryptorchid
Correspondence: Enrico Finale, Dipartimento Materno-Infantile, Ospedale Castelli Verbania, Via Fiume 18, 28922 Verbania (VB), Italy. Tel. +39.0323.541333 - Fax: +39. 0323.541334 E-mail: enrico.finale@gmail.com

Key words: Mowat Wilson syndrome; general anesthesia, anesthesia-related risk.

Acknowledgements: the authors would like to thank Italian Association of the Mowat-WilsonSyndrome.

Contributions: MS, LG, PCM, UE, EF, AG substantial contributions to the conception design of the work, the acquisition, analysis and interpretation of data; MS, LG, PCM, UE, EF, AG drafting the work and revising it critically for important intellectual content; MS, LG, PCM, UE, EF, AG final approval of the version published; MS, LG, PCM, UE, EF, AG agreement to be accountable for all aspects of the work in ensuring that questions related to the accuracy and integrity of any part of the work are appropriately investigated and resolved.

Conflict of interest: the authors declare no potential conflict of interests.

Funding: none.

Received for publication: 30 November 2017. Revision received: 14 February 2018.

Accepted for publication: 28 February 2018

This work is licensed under a Creative Commons Attribution NonCommercial 4.0 License (CC BY-NC 4.0).

(C) Copyright M. Spunton et al., 2018

Licensee PAGEPress, Italy

Pediatric Reports 2018; 10:7514

doi:10.4081/pr.2018.7514

testicle (13,5\%); hypospadias correction $(5,4 \%)$ (Figure 2). Unfortunately it was not possible to derive from the interviews the duration of the single surgical and instrumental procedures.

$75.7 \%$ of families reported that the anesthesiologists were not aware of the syndrome; nevertheless, $43.2 \%$ of parents declared that they have been sufficiently reassured by the competence of the physician to trust him/her, even if we do not have data that attest to the clinical experience of anesthetists with pediatric patients.

In $78.4 \%$ of cases no complications of anesthesia emerged during the procedures (data collected from patients' perception of patients and not from clinical data). Two patients reported anesthesia-related problems: a patient had cardiac complication during one procedure and another patient had respiratory complications during two 
different procedures.

Anesthesia was required for 33 elective procedures and for 4 urgent procedures. No one of the parents received a report after the procedure.

\section{Discussion}

The involvement of patients' organizations in collecting clinical data has been a strong instrument for natural history of rare diseases. The anesthetic risk is present at each procedure but particular syndromes may provide an additional risk. ${ }^{18}$ However, very little is known about the anesthetic risk of MWS. The survey through social media has advantages and disadvantages, as well summarized in a recent article by William Davies: 19 fast turnaround, low costs, a large number of patients recruited (often seen individually in different hospitals) but the evaluation of the point of view of the individuals or the caregivers, the compilation of retrospective questionnaire was on a voluntary basis and this may introduce an additional bias.

However, a similar investigation made for the MWS was done in the same manner for the Cri du Chat syndrome. ${ }^{20}$

Analysis of the type of surgery allows to note that most of these are made in election, except for those made in urgency (i.e. digestive canal at birth), when the diagnosis of MW has not yet been made.

No true additional anesthesia-related risk was present for the patients with MW syndrome, both parents and professionals can take comfort in knowing the real anesthesiologic risk linked to issues involving the Mowat-Wilson syndrome. It is recommended to carry out an examination of patient's cardiac function before any procedure; in case of cardiac malformation, antibiotic prophylaxis for bacterial endocarditis is required. Furthermore, in according to Deshmukt et al., ${ }^{21}$ the main anesthetic challenges in MW syndrome are a risk of difficult intubation and possibility of difficulty in weaning, lower respiratory tract infection and anemia.

The recollections of the patient's parents may be biased, even if it was their choice whether or not to participate in the study, hence we can assume that their responses correspond to reality, but not as a real clinical evaluation.

Table 1. Age of surgery and diagnostic procedures in 11 Italian patients with MWs.

\begin{tabular}{|c|c|c|c|c|c|c|}
\hline Patient & Age & $\begin{array}{l}\text { Type of diagnostic/ } \\
\text { surgical procedure }\end{array}$ & $\begin{array}{l}\text { Elective/ } \\
\text { urgent procedure }\end{array}$ & $\begin{array}{l}\text { Patient's trust in the } \\
\text { anesthesiologist }\end{array}$ & Complications & Hospital stay \\
\hline PT1 & $3 \mathrm{yr}$ & megacolon resection & elective & excellent & no & $9 \mathrm{~d}$ \\
\hline PT2 & $\begin{array}{c}18 \mathrm{mo} \\
3 \mathrm{yr}\end{array}$ & $\begin{array}{l}\text { brain MRI } \\
\text { brain MRI }\end{array}$ & $\begin{array}{l}\text { elective } \\
\text { elective }\end{array}$ & $\begin{array}{l}\text { good } \\
\text { good }\end{array}$ & $\begin{array}{l}\text { no } \\
\text { no }\end{array}$ & $\begin{array}{l}2 \mathrm{~d} \\
2 \mathrm{~d}\end{array}$ \\
\hline PT3 & $\begin{array}{l}52 \mathrm{~d} \\
8 \mathrm{yr}\end{array}$ & $\begin{array}{l}\text { megacolon resection } \\
\text { undescended testicle }\end{array}$ & $\begin{array}{l}\text { urgent } \\
\text { elective }\end{array}$ & $\begin{array}{l}\text { very good } \\
\text { good }\end{array}$ & $\begin{array}{l}\text { no } \\
\text { no }\end{array}$ & $\begin{array}{l}11 \mathrm{~d} \\
3 \mathrm{~d}\end{array}$ \\
\hline PT4 & $\begin{array}{l}21 \mathrm{~d} \\
27 \mathrm{~d} \\
29 \mathrm{~d} \\
80 \mathrm{~d}\end{array}$ & $\begin{array}{l}\text { diagnostic bronchoscopy } \\
\text { cardiac catheterization } \\
\text { vascular ring correction + PDA closure } \\
\text { transanal endorectal pull-through }\end{array}$ & $\begin{array}{l}\text { elective } \\
\text { elective } \\
\text { urgent } \\
\text { elective }\end{array}$ & $\begin{array}{l}\text { satisfactory } \\
\text { satisfactory } \\
\text { satisfactory } \\
\text { N/A }\end{array}$ & $\begin{array}{l}\text { no } \\
\text { no } \\
\text { no } \\
\text { no }\end{array}$ & $\begin{array}{l}2 \mathrm{~d} \\
5 \mathrm{~d} \\
7 \mathrm{~d} \\
11 \mathrm{~d}\end{array}$ \\
\hline PT5 & $\begin{array}{c}3 \mathrm{mo} \\
3 \mathrm{yr}\end{array}$ & $\begin{array}{l}\text { cardiac catheterization + PDA closure } \\
\text { adenotonsillectomy }\end{array}$ & $\begin{array}{l}\text { elective } \\
\text { elective }\end{array}$ & $\begin{array}{l}\text { very good } \\
\text { good }\end{array}$ & $\begin{array}{l}\text { no } \\
\text { no }\end{array}$ & $\begin{array}{l}6 \mathrm{~d} \\
3 \mathrm{~d}\end{array}$ \\
\hline PT6 & $\begin{array}{l}16 \mathrm{mo} \\
19 \mathrm{mo}\end{array}$ & $\begin{array}{l}\text { cardiac catheterization } \\
\text { brain MRI }\end{array}$ & $\begin{array}{l}\text { elective } \\
\text { elective }\end{array}$ & $\begin{array}{l}\text { very good } \\
\text { very good }\end{array}$ & $\begin{array}{l}\text { cardiac } \\
\text { no }\end{array}$ & $\begin{array}{l}5 \mathrm{~d} \\
2 \mathrm{~d}\end{array}$ \\
\hline PT7 & $\begin{array}{l}1 \mathrm{mo} \\
6 \mathrm{mo} \\
9 \mathrm{mo} \\
30 \mathrm{mo} \\
4 \mathrm{yr} \\
5 \mathrm{yr} \\
16 \mathrm{yr}\end{array}$ & $\begin{array}{l}\text { colostomy confection } \\
\text { bowel resection } \\
\text { colostomy reversal } \\
\text { MRI } \\
\text { hypospadias } \\
\text { MRI } \\
\text { undescended testicle removal }\end{array}$ & $\begin{array}{l}\text { elective } \\
\text { elective } \\
\text { elective } \\
\text { elective } \\
\text { elective } \\
\text { elective } \\
\text { elective }\end{array}$ & $\begin{array}{l}\text { satisfactory } \\
\text { satisfactory } \\
\text { satisfactory } \\
\text { satisfactory } \\
\text { satisfactory } \\
\text { satisfactory } \\
\text { satisfactory }\end{array}$ & $\begin{array}{l}\text { no } \\
\text { no } \\
\text { no } \\
\text { no } \\
\text { no } \\
\text { no } \\
\text { no }\end{array}$ & $\begin{array}{l}3 \mathrm{~d} \\
6 \mathrm{~d} \\
7 \mathrm{~d} \\
2 \mathrm{~d} \\
4 \mathrm{~d} \\
2 \mathrm{~d} \\
5 \mathrm{~d}\end{array}$ \\
\hline PT8 & $\begin{array}{l}1 \mathrm{mo} \\
3 \mathrm{mo} \\
1 \mathrm{yr} \\
7 \mathrm{yr}\end{array}$ & $\begin{array}{l}\text { pulmonic valve stenosis surgery } \\
\text { pyloric stenosis } \\
\text { IVD closure } \\
\text { vertebral column arthrodesis }\end{array}$ & $\begin{array}{l}\text { elective } \\
\text { urgent } \\
\text { elective } \\
\text { elective }\end{array}$ & $\begin{array}{l}\text { very poor } \\
\text { very poor } \\
\text { very poor } \\
\text { very good }\end{array}$ & $\begin{array}{l}\text { respiratory } \\
\text { no } \\
\text { respiratory } \\
\text { no }\end{array}$ & $\begin{array}{l}5 \mathrm{~d} \\
3 \mathrm{~d} \\
4 \mathrm{~d} \\
7 \mathrm{~d}\end{array}$ \\
\hline PT9 & $\begin{array}{c}1 \mathrm{mo} \\
6 \mathrm{mo} \\
9 \mathrm{mo} \\
4 \mathrm{yr} \\
16 \mathrm{yr} \\
21 \mathrm{yr}\end{array}$ & $\begin{array}{l}\text { megacolon } \\
\text { bowel resection } \\
\text { colostomy reversal } \\
\text { hypospadias } \\
\text { undescended testicle removal } \\
\text { brain MRI + urethrotomy }\end{array}$ & $\begin{array}{l}\text { urgent } \\
\text { elective } \\
\text { elective } \\
\text { elective } \\
\text { elective } \\
\text { elective }\end{array}$ & $\begin{array}{l}\text { good } \\
\text { good } \\
\text { good } \\
\text { good } \\
\text { good } \\
\text { good }\end{array}$ & $\begin{array}{l}\text { no } \\
\text { no } \\
\text { no } \\
\text { no } \\
\text { no } \\
\text { no }\end{array}$ & $\begin{array}{l}7 \mathrm{~d} \\
4 \mathrm{~d} \\
7 \mathrm{~d} \\
3 \mathrm{~d} \\
4 \mathrm{~d} \\
3 \mathrm{~d}\end{array}$ \\
\hline PT10 & $\begin{array}{l}6 \mathrm{mo} \\
3 \mathrm{yr} \\
3 \mathrm{yr}\end{array}$ & $\begin{array}{l}\text { MRI } \\
\text { MRI } \\
\text { facial and hand warts excision }\end{array}$ & $\begin{array}{l}\text { elective } \\
\text { elective } \\
\text { elective }\end{array}$ & $\begin{array}{l}\text { satisfactory } \\
\text { satisfactory } \\
\text { good }\end{array}$ & $\begin{array}{l}\text { no } \\
\text { no } \\
\text { no }\end{array}$ & $\begin{array}{l}2 \mathrm{~d} \\
1 \mathrm{~d} \\
2 \mathrm{~d}\end{array}$ \\
\hline PT11 & $\begin{array}{l}11 \mathrm{mo} \\
1 \mathrm{yr} \\
18 \mathrm{mo} \\
4 \mathrm{yr}\end{array}$ & $\begin{array}{l}\text { tear duct opening + orchidopexy } \\
\text { MRI } \\
\text { muscle biopsy } \\
\text { testicle removal }\end{array}$ & $\begin{array}{l}\text { elective } \\
\text { elective } \\
\text { elective } \\
\text { elective }\end{array}$ & $\begin{array}{l}\text { satisfactory } \\
\text { satisfactory } \\
\text { satisfactory } \\
\text { satisfactory }\end{array}$ & $\begin{array}{l}\text { no } \\
\text { no } \\
\text { no } \\
\text { no }\end{array}$ & $\begin{array}{l}5 \mathrm{~d} \\
2 \mathrm{~d} \\
1 \mathrm{~d} \\
5 \mathrm{~d}\end{array}$ \\
\hline
\end{tabular}




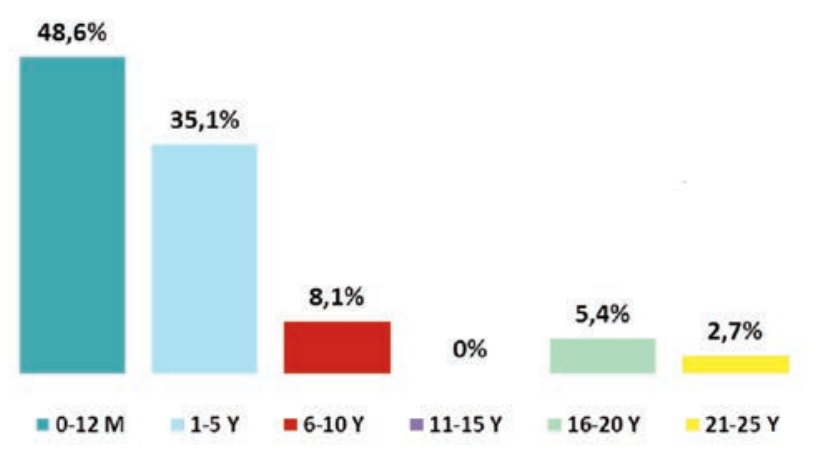

Figure 1. The age of patients as a percentage. At the time of general anesthesia, the age of patients ranged from month to 21 years.

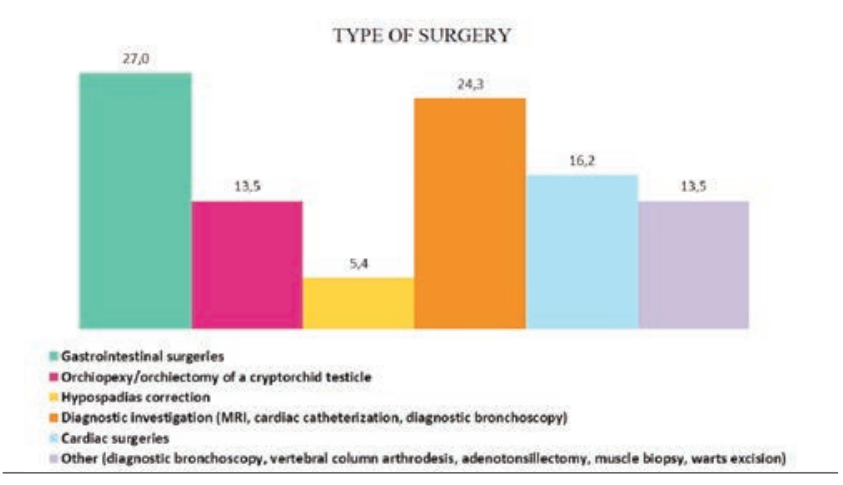

Figure 2. Type of surgery and diagnostic procedures in 11 Italian patients with MWs.

\section{Conclusions}

The study presents possible limits, such as potential bias due to the set nature of the design: a retrospective survey based on the memory of the patients' parents. Moreover, the lack of some clinical data such as the duration of surgical and instrumental procedures, ASA score, the experience of the anesthetists inherent in pediatric patients, the anesthetic technique used, do not make the present study definitive. However our perception of risk, however, is derived by non-medical observation on the part of the parents, therefore further investigations including the analysis of the medical files of all subject - are needed to confirm our findings; a prospective study would be desirable.

\section{References}

1. Adam MP, Bean LJH, Ranger Miller V. Mowat-Wilson sindrome. Genereviews www.genetests.org

2. Bissonnette B, Luginbruehl I, Marciniak $\mathrm{B}$, et al. Syndromes: rapid recognition and perioperative implications. McGraw-Hill, 2006.

3. Cacheux V, Dastot-Le Moal F, Kääriäinen $\mathrm{H}$, et al. Loss-of-function mutations in SIP1 Smad interacting protein 1 results in a syndromic Hirschsprung disease. Hum Mol Genet 2001;10:1503-10.

4. Cerutti Mainardi P, Pastore G, Zweier C, et al. Mowat-Wilson sindrome and mutation in the zinc finger homeo box 1B gene: a well defined clinical entity $\mathbf{J}$ Med Genet 2004;41:e16.
5. Dastot-Le Moal F, Wilson M, Mowat D, et al. ZFHX1B mutations in patients with Mowat-Wilson syndrome. Hum Mutat 2007:1-9.

6. Garavelli L, Donadio A, Zanacca C, et al. Hirschsprung disease, mental retardation, characteristic facial features and mutation in the gene ZFHX1B (SIP1): confirmation of the MowatWilson syndrome. Am J Med Genet 2003;116A 385-8.

7. Garavelli L, Mainardi PC. MowatWilson syndrome. Orphanet J Rare Dis 2007;2:42.

8. Garavelli L, Zollino M, Mainardi PC, et al. Mowat-Wilson Syndrome: phenotype changing with age. Study of 19 Italian patients and review of the literature. Am J Med Genet Am 2009;149A:417-26.

9. Kiernan F, Crowe S. Safe use of the classic laryngeal mask airway and endotracheal intubation in general anaesthesia for a patient with MowatWilson syndrome. Paediatr Anaesth 2009;19:174-5.

10. Mowat DR, Croaker GDH, Cass DT, et al. Hirschsprung disease, microcephaly, mental retardation, and characteristic facial features: delineation of a new syndrome and identification of a locus at chromosome 2q22-q23. J Med Genet 1998;35:617-23.

11. Mowat DR, Wilson MJ, Goossens M. Mowat-Wilson syndrome J Med Genet 2003;40:305-10.

12 - Electronic Database Information: Online Mendelian Inheritance in Man (OMIM), http://www.ncbi.nlm.nih.gov/Omim/

13. Wakamatsu N, Yasukazu Y, Kenichiro Y, et al. Mutations in SIP1, encoding Smad interacting protein-1, cause a form of Hirschsprung disease. Nat Genet 2001;27:369-70.

14. Wilson M, Mowat D, Dastot-LeMood F. Further delineation of the phenotype associated with heterozygous mutation in ZFHX1B. Am J Med Genet 2003;119A:257-65.

15. Zweier C, Albrecht B, Mitulla B, et al. Mowat-Wilson Syndrome with and without Hirschsprung Disease is a distinct, recognizable Multiple Congenital Anomalies-Mental Retardation Syndrome caused by Mutations in the Zinc finger homeobox 1 B gene (ZFHX1B). Am J Med Genet 2002;108:177-81.

16. Zweier C, Temple IK, Beemer F, et al. Characterisation of deletions of the ZFHX1B region and genotypephenotype analysis in Mowat-Wilson syndrome. J Med Genet 2003;40:601-5.

17. Zweier C, Thiel CT, Dufke A, et al. Clinical and Mutational Spectrum of Mowat-Wilson Sindrome. Eur J Med Genet 2005, 48: 97-111.

18. Biro P, Vagts D, Emmig U, et al. Anasthesie bei seltenen Erkrankungen. Berlin: Springer-Verlag 2011.

19. Davies W. Insights into rare diseases from social media surveys. Orphan J Rare Dis 2016,11:151-5.

20. Guala A, Spunton M, Mainardi PC, et al. Anesthesia in Cri du Chat syndrome: information on 51 Italian patients. Am J Med Genet 2015,167A:1168-70.

21. Deshmukt AS, Kelkar KV, Khedkar SM, et al. Anaesthetic management of Mowat-Wilson syndrome. Ind J Anaesthesia 2016,40:292-3. 